\title{
Marketability of Value-added Pumpkin (Cucurbita moschata Duch.) Fruit in a Representative Peri-urban Kenyan Market
}

\author{
Jedidah Wanjiku Kiharason ${ }^{1}$, Dorcas Khasungu Isutsa ${ }^{2}$ \\ ${ }^{1}$ Department of Environmental Studies and Resources Development, Chuka University, Chuka, Kenya \\ ${ }^{2}$ Department of Plant Sciences, Chuka University, Chuka, Kenya, and Department of Horticulture, Egerton University, Egerton, Kenya
}

Email address:

dorcaski@yahoo.com (D. K. Isutsa)

\section{To cite this article:}

Jedidah Wanjiku Kiharason, Dorcas Khasungu Isutsa. Marketability of Value-added Pumpkin (Cucurbita moschata Duch.) Fruit in a Representative Peri-urban Kenyan Market. International Journal of Food Science and Biotechnology. Vol. 4, No. 1, 2019 , pp. 7-13. doi: $10.11648 /$ j.ijfsb.20190401.12

Received: January 20, 2019; Accepted: February 27, 2019; Published: March 19, 2019

\begin{abstract}
Pumpkin (C. moschata Duch.) fruit is a highly nutritious horticultural crop with great potential for commercialization. However, in Kenya many households do not buy and utilize pumpkins regularly, leading to low demand. These scenarios increase post-harvest losses and provide no incentive for farmers to increase production in Kenya, which has an abundance of pumpkin landraces that unfortunately remain under-exploited and under-utilized. Their distribution and marketing is a great challenge due to easy perishability. Horticultural crops experience losses in quality and quantity in between harvest and consumption. The magnitude of post-harvest losses in fresh fruits and vegetables is estimated to range from $20 \%$ to $50 \%$ in developing countries. The present study determined marketability of fresh fruit, and the spoilage rate of fresh fruit in the various presentation formats (eighth, quarter and half slices and a control of whole fruit either wrapped or not with cling film). Selling was facilitated by four market women in Nyeri County of Kenya. Statistical analysis showed significant differences $(P<0.05)$ in number of spoilt pieces over time, and between number of days to spoilage of whole fruit, compared to slice fruit. More quarter and half slices got spoiled after a few days of presentation to buyers. Nonetheless, quarter slices had the highest (54.5\%) pieces sold, while half slices had the fewest $(9.8 \%)$ pieces sold. However, no significant differences occurred in average number of pieces sold, or in amount of money from sale of fruit pieces of different presentation formats. Most consumers preferred buying smaller slices. Therefore, adoption and promotion of pumpkin presentation formats that effectively increase shelf-life is recommended to enhance production and utilization in Kenya.
\end{abstract}

Keywords: Pumpkin, Sale, Fruit, Post-harvest, Spoilage, Presentation Format

\section{Introduction}

Africa has an abundance of indigenous and traditional crops which unfortunately remain under-exploited and underutilized due to various constraints, including lack of effective processing, distribution and marketing arrangements, as well as nutrition information [1-8]. The rapid perishability of fresh produce poses major challenges in distribution and marketing. Perishability of horticultural produce is one of the central problems facing developing countries, since it results in massive spoilage of needed fresh food. As time goes on, these problems are aggravated by the growing dietary needs of populations in these countries [9]. In Africa and Kenya in particular, this problem confronts many fruit and vegetable crops, since it results in wastage during the in-season and limited supply during the off-season. Fresh fruits cannot be marketed fast enough when they are in-season owing to their short shelf-life. Appropriate preservation and storage methods should be devised to facilitate consumption of nutrient-rich fruits all year round [10].

Post-harvest loss (PHL) is the measurable quantitative and qualitative food loss in the post-harvest system which comprises interconnected activities from the time of harvest through crop processing, marketing and food preparation, to the final decision by the consumer to eat or discard the food [11-12]. Post-harvest handling refers to subsequent processes performed immediately after removing a plant or plant part from its growth environment until the removed plant or plant part reaches the final consumer in the desired form of packaging, quantity, quality and price. Conventionally, the 
value chain encompasses cooling, sorting, cleaning, packaging, processing or shipping to wholesale or consumer retail markets [13].

Along with roots and tubers, fruits and vegetables have the highest wastage rates of all food products [14]. The magnitude of post-harvest losses in fresh fruits and vegetables is estimated to range from $5 \%$ to $25 \%$ in developed countries, while in some African countries it has been estimated that about $30 \%$ of produce is lost, and this figure can rise up to $50 \%$ for very perishable foods such as fruits and vegetables [13-16]. Losses have been reported to go up to $80 \%$ in some developing countries [16]. Losses occur in the field, during transportation, storage and processing. Insects, bacteria and fungi are often responsible for severe loss of nutritive value in food. When bacteria and fungi infect produce, unfavourable chemical changes occur. Some fungi produce carcinogenic toxins rendering food unsuitable for human or animal consumption [13]. Improper handling, storage, preservation techniques and microorganism spoilage raise PHL in fruits and vegetables to $40 \%$ [17].

Visual microbial growth on the fruits has been used as a main criterion to determine shelf-life of fruit pieces stored under controlled atmosphere conditions [18]. Water soaked appearance is common in most crop produce [19]. Microbial spoilage results in $30-50 \%$ shrinkage of fresh-cut fruits and has been used by quality assurance departments as the objective indicator of quality failure for more than $50 \%$ of fresh-cut vegetables and almost $100 \%$ of fresh-cut fruits [19]. Many fruits have nearly ideal conditions for growth of most microorganisms where internal tissues are nutrient-rich and many have near neutral $\mathrm{pH}$. Uncut fruit is covered by an outer protective epidermis which is in turn typically covered by a natural waxy cuticle layer containing the polymer cutin [20]. Once the covers are destroyed by bruising or slicing the fruit, water loss and eventual spoilage ensure. Spoilage microorganisms infect the host using extracellular lytic enzymes that degrade the polymers (cellulose, hemicellulose, pectin and majorly starch) to release water and other constituents. Fungi produce diverse and greater amounts of extracellular depolymerases which successfully attack and spoil fresh fruit and vegetable crops [21].

Subrahmanyam [22] reported that PHLs not only reduce the availability of fruits and vegetables, but also result in increase in per unit cost of transport and marketing. These effects affect both the producers (reduction in share of consumers' price) and consumers (reduced availability and higher prices). Reducing PHL along with making more effective use of today's crops is critical in facing the challenge of feeding increasing world population [11].

Pumpkin is a multi-purpose crop whose fruit has a yelloworange characteristic colour due to abundant carotenoids [2325]. Previous research indicates that diets rich in foods containing the antioxidant beta-carotene may reduce the risk of some types of cancer and protect against heart disease. Antioxidants are required to boost the human body immunity against cancer and other deadly human diseases. Pumpkin fruit is rich in carbohydrates, proteins and micronutrients, such that no other single food has such high nutritional potential $[8,26,27]$. Moreover, pumpkin fruit is not as bulky as tubers such as the yam, and can be used as a breakfast food $[7,8]$. Its production is less labour-intensive and more profitable compared to yam and many other staple crops [2629].

Internationally, records have indicated minor or inexistent trade of pumpkin leaves, fruits and seed, but at national level the leaves and fruits and often the seeds are important products on local markets [24]. Cucurbita moschata is most probably cultivated in all countries of tropical Africa, but it is more important in Southern Africa than in Eastern and Western Africa [24]. It has been reported as lacking commercial importance in Nigeria and even in Kenya [2, 30]. Studies have also reported pumpkin as a crop which is not valued as a sales crop compared to other horticultural crops which are widely grown for household consumption, as well as for sale by Kenyan farmers [2, 31]. Ondigi and colleagues [32] reported that majority of farmers in the Lake Victoria basin did not consider pumpkin as a first priority food crop as much as it was not considered a viable commercial crop and was ranked fifth or sixth food crop by farmers in the region.

Nonetheless, pumpkin is a traditional crop with high potential to overcome undernourishment and food poverty [3, 6] and [32-33], yet very little has been done to generate income from this crop even amidst favourable ecological conditions throughout East Africa [28-29, [31, 34]. The present study determined marketability of fresh pumpkin fruit in various presentation formats (eighth slices, quarter slices, half slices and whole fruit), as well as established spoilage rate of fresh fruit in the various presentation formats. It had two hypotheses: (1) Packaging fresh pumpkin fruit into various formats does not enhance sales in the market; (2) Packaging fresh pumpkin fruit into various presentation formats does not prolong shelf-life.

\section{Materials and Methods}

\subsection{Research Set Up}

The evaluation of pumpkin fruit marketability involved four market women who were provided with fruit stocks to sell over a 14-day period. They were instructed on the various presentation formats, namely: whole fruit (control), fruit sliced once (into halves), sliced twice (into quarters) and sliced four times (into eighths) and then wrapped with clear shrink wrap polythene. Records were kept on quantities sold each day over the period to identify the income generated from each of the presentation formats. The format with more pieces sold hence least wastage was considered optimal. The display of the different fruit presentations at the market was done randomly; i.e. the space and placement of each format was not done in any logical sequence which could influence the customers' choice. In addition to the market test, a controlled experiment was done in laboratory to compare spoilage rates among different presentation formats namely: 
whole fruit, sliced into halves, sliced into quarters, and sliced into eighths, and then either wrapped with clear shrink wrap polythene or not wrapped. Shelf-life was determined at twoday intervals by recording weight loss and days the slices remained in observable acceptable condition.

\subsection{Data Analysis}

Data values were subjected to analysis of variance to determine if there were significant differences in sales, number of pieces sold, number of pieces spoilt and total sale across different days. The least significance difference was used to separate means which were significantly different at $\alpha=5 \%$.

\section{Results}

\subsection{Marketability of Value-added Fruits}

Marketability was evaluated by recording the total number of pieces sold for the day and the amount of money received from sale of different presentation formats. Total number of pieces sold would help to establish the presentation format which performed best in market, not only considering the amount of money received but also considering the number of customers who preferred that specific presentation format. Table 1 shows total amount of money received from sale of fruits from days 1 to 14 . Generally, quarter slices and whole fruit fetched more money each day (but for a few exceptions like day 2 and 4 where there were no sales at all for whole fruit and in day 7 and 8 which had half slices realizing higher sales compared to whole fruit). It is noted that in total, sale of whole fruits realized the highest amount (KSh. 2,375/- which was received from sale of an average total of 15.75 fruits over the 14-day period). Of the sliced fruit, quarter slices had the highest sales (KSh. 1,440/- from 36 slices). It is notable that eighth slices realized the least amount of sale. There were no significant differences in the amount of money received from sale of fruit from each of the presentation formats over the days.

Table 1. Mean total sales of fruits in various presentation formats.

\begin{tabular}{|c|c|c|c|c|}
\hline Day & Eighth slices & Quarter slices & Half slices & Whole fruit \\
\hline 1 & $20.00 \mathrm{ab}^{*}$ & $120.00 \mathrm{ab}$ & $35.00 \mathrm{a}$ & $62.50 \mathrm{~cd}$ \\
\hline 2 & $5.00 \mathrm{ab}$ & $50.00 \mathrm{~b}$ & $12.50 \mathrm{a}$ & $0.00 \mathrm{~d}$ \\
\hline 3 & $0.00 \mathrm{~b}$ & $120.00 \mathrm{ab}$ & $32.50 \mathrm{a}$ & $25.00 \mathrm{~d}$ \\
\hline 4 & $10.00 \mathrm{ab}$ & $60.00 \mathrm{ab}$ & $25.00 \mathrm{a}$ & $0.00 \mathrm{~d}$ \\
\hline 5 & $0.00 \mathrm{~b}$ & $100.00 \mathrm{ab}$ & $20.00 \mathrm{a}$ & 187.50abcd \\
\hline 6 & $15.00 \mathrm{ab}$ & $90.00 \mathrm{ab}$ & $57.50 \mathrm{a}$ & $167.50 \mathrm{abcd}$ \\
\hline 7 & $20.00 \mathrm{ab}$ & $70.00 \mathrm{ab}$ & $50.00 \mathrm{a}$ & $37.50 \mathrm{~d}$ \\
\hline 9 & $30.00 \mathrm{ab}$ & $120.00 \mathrm{ab}$ & $0.00 \mathrm{a}$ & $412.50 \mathrm{ab}$ \\
\hline 10 & $0.00 \mathrm{~b}$ & $140.00 \mathrm{ab}$ & $20.00 \mathrm{a}$ & $275.00 \mathrm{abcd}$ \\
\hline 11 & $20.00 \mathrm{ab}$ & $160.00 \mathrm{a}$ & $27.50 \mathrm{a}$ & $475.00 \mathrm{a}$ \\
\hline 12 & $5.00 \mathrm{ab}$ & $90.00 \mathrm{ab}$ & $37.50 \mathrm{a}$ & 200.00abcd \\
\hline 13 & $20.00 \mathrm{ab}$ & $100.00 \mathrm{ab}$ & $25.00 \mathrm{a}$ & $370.00 \mathrm{abc}$ \\
\hline 14 & $5.00 \mathrm{ab}$ & $160.00 \mathrm{a}$ & $45.00 \mathrm{a}$ & $112.50 \mathrm{bcd}$ \\
\hline Total sales (sh.) & 160.00 & $1,440.00$ & 465.00 & $2,375.00$ \\
\hline
\end{tabular}

*Values followed by the same letter within a column are not significantly different at $\alpha=0.05$.

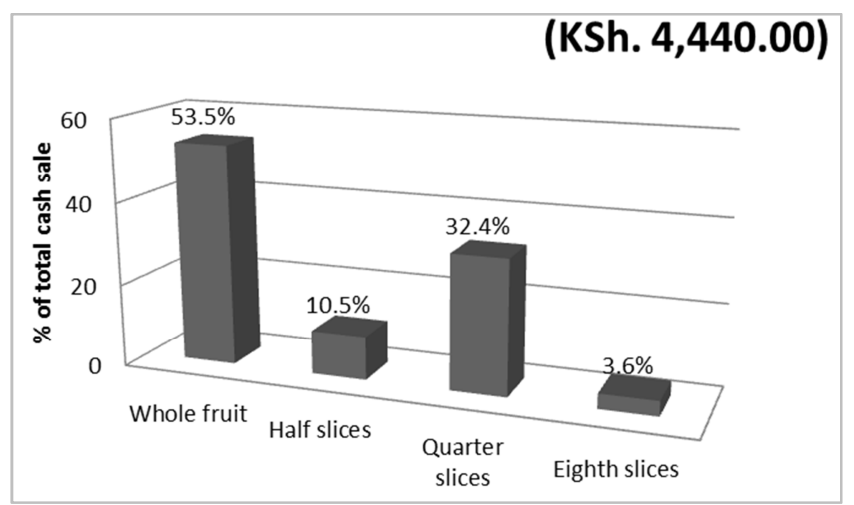

Figure 1. Percentage of total cash from sale of various fruit presentation formats.

Furthermore, the amount of money from fruit sales was compared to determine contribution from each presentation format. Out of a total of KSh. 4,440/- received from the sales over the 14-day period, whole fruit fetched more than half $(53.5 \%)$ of this amount (Figure 1). Of the sliced pieces, quarter slices had the highest sales percentage, while eighth slices had the least sales (3.6\%).

It was found that quarter slices had the most sales over the selling period, which averaged 2.5 fruits per day. Table 2 shows that quarter slices had a total sale of 36 pieces in the 14-day period. In days 11 and 14, quarter slices attained an average of 4 fruits sold and no zero sale in any day. This was contrary to all the other presentation formats which had at least one day with zero sale, whereby the eighth slices had the most number of days (three) with completely no sale. The half slices, however, were the least sold at only 6.5 pieces in total during the entire period. There were no significant differences among the number of fruit pieces sold per day in all the presentation formats.

Spoilage was observed only in quarter and half slices. Day 
four had the highest average number of spoilt pieces in both presentation formats compared to the other days. The quarter slices had seven consecutive days without any fruit spoilage during the second week. More spoilage occurred in half slices, with a total of 4.25 fruits (39.5\%) getting spoilt, while quarter slices had $10 \%$ of total quarter slices handled getting spoilt. There were significant differences $(P<0.05)$ in the spoilt pieces (both quarter and half slices) over the different selling days.

Table 2. Mean pieces (slices) of pumpkin fruits sold or spoilt per day.

\begin{tabular}{|c|c|c|c|c|c|c|}
\hline \multirow{2}{*}{ Day } & \multicolumn{4}{|c|}{ Daily sales (number of pieces) } & \multicolumn{2}{|c|}{ Spoilage (pieces/day) } \\
\hline & Eighth & Quarter & Half & Whole & Quarter & Half \\
\hline 1 & $1.00 \mathrm{ab} *$ & $3.00 \mathrm{ab}$ & $0.50 \mathrm{a}$ & $0.50 \mathrm{bcd}$ & $0.00 \mathrm{~b}$ & $0.00 \mathrm{c}$ \\
\hline 2 & $0.25 \mathrm{ab}$ & $1.25 \mathrm{~b}$ & $0.25 \mathrm{a}$ & $0.00 \mathrm{~d}$ & $0.00 \mathrm{~b}$ & $0.00 \mathrm{c}$ \\
\hline 3 & $0.00 \mathrm{~b}$ & $3.00 \mathrm{ab}$ & $0.50 \mathrm{a}$ & $0.25 \mathrm{~cd}$ & $1.50 \mathrm{a}$ & $0.00 \mathrm{c}$ \\
\hline 4 & $0.50 \mathrm{ab}$ & $1.50 \mathrm{ab}$ & $0.50 \mathrm{a}$ & $0.00 \mathrm{~d}$ & $1.75 \mathrm{a}$ & $2.00 \mathrm{a}$ \\
\hline 5 & $0.00 \mathrm{~b}$ & $2.50 \mathrm{ab}$ & $0.25 \mathrm{a}$ & $1.50 \mathrm{abcd}$ & $0.25 b$ & $0.00 \mathrm{c}$ \\
\hline 6 & $0.75 \mathrm{ab}$ & $2.25 \mathrm{ab}$ & $1.00 \mathrm{a}$ & $1.25 \mathrm{abcd}$ & $0.00 \mathrm{~b}$ & $0.00 \mathrm{c}$ \\
\hline 7 & $1.00 \mathrm{ab}$ & $1.75 \mathrm{ab}$ & $0.75 \mathrm{a}$ & $0.25 \mathrm{~cd}$ & $0.50 \mathrm{~b}$ & $0.00 \mathrm{c}$ \\
\hline 8 & $0.50 \mathrm{ab}$ & $1.50 \mathrm{ab}$ & $0.75 \mathrm{a}$ & $0.50 \mathrm{bcd}$ & $0.00 \mathrm{~b}$ & $1.25 \mathrm{ab}$ \\
\hline 9 & $1.50 \mathrm{a}$ & $3.00 \mathrm{ab}$ & $0.00 \mathrm{a}$ & $2.50 \mathrm{ab}$ & $0.00 \mathrm{~b}$ & $0.00 \mathrm{c}$ \\
\hline 10 & $0.00 \mathrm{~b}$ & $3.50 \mathrm{~b}$ & $0.25 \mathrm{a}$ & $2.25 \mathrm{abc}$ & $0.00 \mathrm{~b}$ & $0.25 \mathrm{c}$ \\
\hline 11 & $1.00 \mathrm{ab}$ & $4.00 \mathrm{ab}$ & $0.50 \mathrm{a}$ & $2.75 \mathrm{a}$ & $0.00 \mathrm{~b}$ & $0.75 b c$ \\
\hline 12 & $0.25 \mathrm{ab}$ & $2.25 \mathrm{ab}$ & $0.50 \mathrm{a}$ & $1.25 \mathrm{abcd}$ & $0.00 \mathrm{~b}$ & $0.00 \mathrm{c}$ \\
\hline 13 & $1.00 \mathrm{ab}$ & $2.50 \mathrm{ab}$ & $0.50 \mathrm{a}$ & $2.00 \mathrm{abcd}$ & $0.00 \mathrm{~b}$ & $0.00 \mathrm{c}$ \\
\hline 14 & $0.25 \mathrm{ab}$ & $4.00 \mathrm{a}$ & $0.25 \mathrm{a}$ & $0.75 \mathrm{abcd}$ & $0.00 \mathrm{~b}$ & $0.00 \mathrm{c}$ \\
\hline Total pcs & 8 & 36 & 6.5 & 15.75 & 4 & 4.25 \\
\hline$P$-value & 0.362 & 0.549 & 0.987 & 0.092 & 0.0023 & $<0.0001$ \\
\hline $\mathrm{LSD}_{0.05}$ & 1.275 & 2.684 & 1.324 & 2.064 & 0.9343 & 0.7809 \\
\hline
\end{tabular}

*Values followed by the same letter within a column are not significantly different at $\alpha=0.05$.

The percentage of slices sold for each presentation format was determined by comparing the number sold with the total number of slices for all presentation formats which were sold over the display period. More than half of all the pieces sold were the quarter slices $(54.5 \%)$, while half slices had the least sales $(9.8 \%)$ (Figure 2).

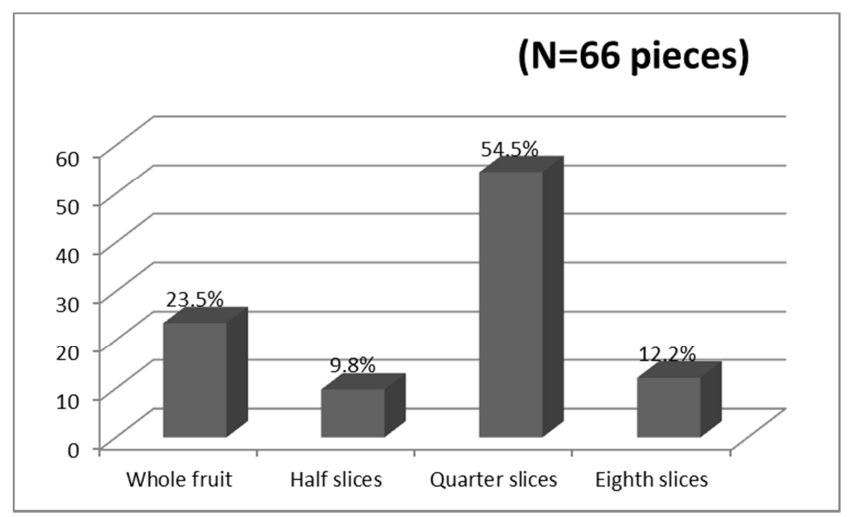

Figure 2. Percentage of pumpkin fruit pieces sold from various presentation formats.

\subsection{Spoilage Rate}

Observation of whole fruit showed that spoilage signs started after an average of 142 days. On the other hand, observation of slices showed that keeping quality of fruit after slicing was drastically reduced, with the fruit beginning to deteriorate sooner and, by day four, undesirable changes were evident rendering the fruit unfit for consumption. By day 4 , the unwrapped fruit had begun to develop moulds, which spread all over the fruit surface by day 6 . The half unwrapped slices took 3 to 4 days before getting spoilt, while their quarter counterparts took 3 days. The wrapped slices were characterized by less mould but had slimy surface under the wrapping, although they had slightly longer shelf stability. Half-cut and wrapped slices took 5 days compared to 4 days for quarter wrapped slices. By day 6 observation showed that all the slices, whether wrapped or unwrapped, were completely spoilt.

Table 3 shows significant differences $(P<0.0001)$ in the number of days it took whole fruit compared with slices to get spoilt. It took a much longer time (142 days) for whole fruit to spoil, while the period taken for the slices to spoil was not significantly different. It is however notable that half wrapped slices took the longest out of the four slice presentations. Quarter unwrapped slices took the shortest average number of days (3) to get spoilt.

Change in weight loss of the various presentation formats is shown in Figure 3. The wrapped slices had a low rate of moisture loss and weight loss, while half slices lost only $17 \mathrm{~g}$ from $809 \mathrm{~g}$ to $792 \mathrm{~g}$ and quarter slices lost $13 \mathrm{~g}$ from $561 \mathrm{~g}$ to $548 \mathrm{~g}$. This was much less as compared to the unwrapped ones where half slices lost $156 \mathrm{~g}$ and quarter slices lost $146 \mathrm{~g}$.

Table 4 shows the difference in weight after every two days since the time fruits were sliced. Wrapped pieces lost much less weight every two days, which ranged from $3.6 \mathrm{~g}$ to $6.2 \mathrm{~g}$, compared to much higher weight loss observed in the unwrapped pieces which was between $34.5 \mathrm{~g}$ and $74.3 \mathrm{~g}$ every two days. More weight loss occurred between the day of slicing and the second day, then reduced with increasing days with least loss occurring between day 4 and 6 . Half slices lost more weight compared to quarter slices. There were significant differences $(P=0.0001)$ between the weight loss of quarter slices and half slices from day zero through day six. 


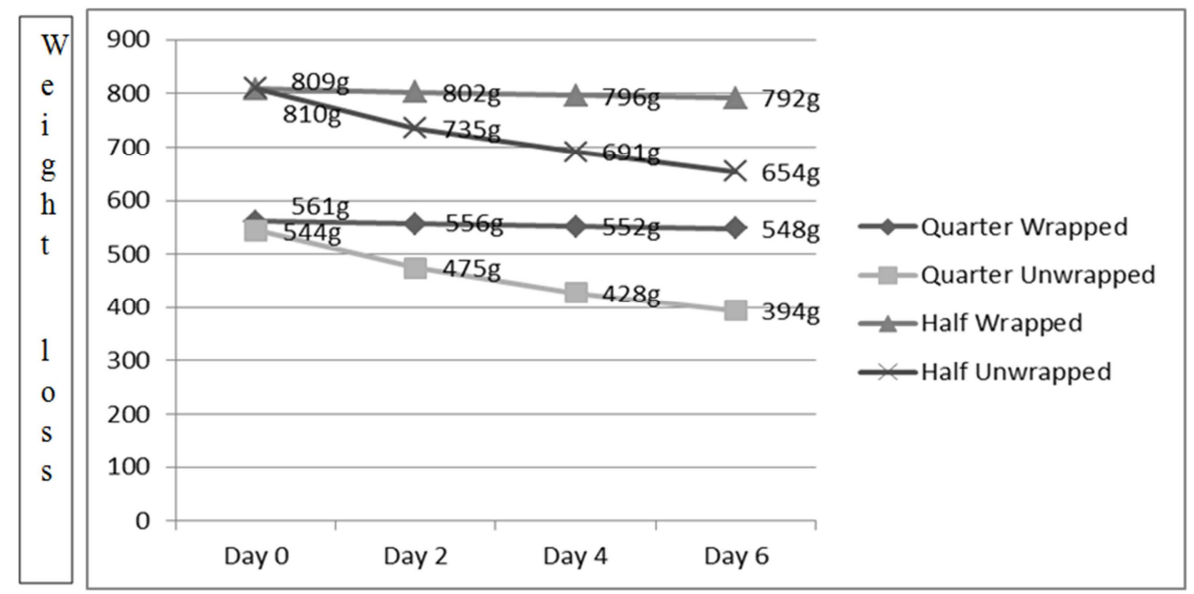

Figure 3. Trend in weight loss of sliced fruits of different presentation formats.

Table 3. Mean number of days before spoilage of whole and sliced fruit.

\begin{tabular}{llll}
\hline Presentation format & Number of days & $\boldsymbol{P}$-value & LSD $_{\mathbf{0 . 0 5}}$ \\
\hline Quarter wrapped & $4.25 \mathrm{~b}^{*}$ & & \\
Quarter unwrapped & $3.00 \mathrm{~b}$ & $<0.0001$ & 26.129 \\
Half wrapped & $4.75 \mathrm{~b}$ & & \\
Half unwrapped & $3.5 \mathrm{~b}$ & $142.5 \mathrm{a}$ & \\
Whole fruit & . & & \\
\hline
\end{tabular}

*Values followed by the same letter within a column are not significantly different at $\alpha=0.05$.

Table 4. Mean weight of differences in days for various fruit presentations.

\begin{tabular}{llll}
\hline Presentation format & Total weight loss by day two & Total weight loss by day four & Total weight loss by day six \\
\hline Quarter wrapped & $5.01 \mathrm{~b}^{*}$ & $4.12 \mathrm{~b}$ & $3.62 \mathrm{~b}$ \\
Quarter unwrapped & $73.12 \mathrm{a}$ & $42.38 \mathrm{a}$ & $34.51 \mathrm{a}$ \\
Half wrapped & $6.20 \mathrm{~b}$ & $5.12 \mathrm{~b}$ & $4.33 \mathrm{~b}$ \\
Half unwrapped & $74.37 \mathrm{a}$ & $44.59 \mathrm{a}$ & $35.66 \mathrm{a}$ \\
$P$-value & $<0.0001$ & $<0.0001$ & $<0.0001$ \\
$\mathrm{LSD}_{0.05}$ & 2.899 & 2.533 & 3.037 \\
\hline
\end{tabular}

*Means followed by the same letter within a column are not significantly different at $\alpha=0.05$.

\section{Discussion}

Sale of pumpkin fruit of different presentation format was almost evenly distributed over time and no single day had sale of three or more whole fruits (even after combining the various pieces sold daily). Amount (size) of fruit purchased and utilized in a single meal is determined by family size. Of the various fruit presentation formats, the quarter slices appeared to be the most convenient size purchased by majority of the customers, probably because it was enough to include in a single family meal (or could last for about two days for a baby's meal). Whole fruit was also purchased by many customers, probably because they utilized the fruit to prepare whole family meals for two or three consecutive days before it began to spoil [11].

Although whole fruits realized the highest amount of money from sale, it was noted that the highest number of customers preferred to buy quarter slices compared to the other presentation formats. Considering that a whole fruit would keep longer (up to 6 months) before spoiling and that slicing the fruit drastically reduced shelf-life to 3-5 days, it was logical for a customer to buy a small slice enough for a single meal befitting daily menu patterns than buy a whole fruit which would end up spoiling before full utilization. A good number of customers also purchased whole fruit and it was assumed that these were good fruit consumers who ensured the fruit was fully consumed before getting spoilt [11].

When the spoilage rate of fruit at the market was compared with that of fruits in controlled experiment, it was observed that market quarter slices took an average of 3 days to spoil, while counterparts in the laboratory took 4.25 days, as half slices took 4 and 4.74 days, respectively. These results indicated that the fruit was spoiling faster in the market than in the laboratory. This response was attributed to the fact that conditions may be a bit harsh in the open market as compared to the laboratory atmosphere where the fruit was stored in a cool place [12]. Fruits in the open market are definitely exposed to more microbial attack than those in the laboratory. Barth et al. [21] indicated that bruising the waxy cuticle layer of fruit or slicing the fruit leads to water loss which eventually results in spoilage). The results of the present study showed that wrapping the fruit slices played a role in preserving the fruit by reducing the rate of water loss 
from the fruit [12]. On the other hand, unwrapped fruit formats lost a lot of water. Overall, slicing drastically reduced shelf-life compared to whole fruit presentation.

Observations on market fruit showed that quarter slices never had any spoilage in the second week probably due to higher average daily sales hence the already cut fruit did not stay for too long to get spoilt before the stock was cleared. It was also found that whole fruit did not show any spoilage over the entire selling period, which was expected due to the longer shelf-life of whole pumpkin fruit, which was observed to be an average of 142 days. Ndoro et al. [35] indicated that undamaged whole pumpkin fruit with the peduncle attached was able to keep for periods ranging from 2 to 6 months and that removal of the peduncle greatly reduced the storage period of the pumpkin fruit $[9,11]$.

\section{Conclusions and Recommendations}

There was no predictable pattern of fruit sale in the market and no significantly higher sales in any given day compared to the other days. There was no sale of more than three fruits in any single day, whether from whole fruit or in any of the sliced formats. It was, therefore, concluded that pumpkin fruit sale is not very popular in the study area. Consequently, consumption of the fruit is likely to be low especially among urban dwellers that are most likely to have no alternative source of the fruit besides the market. There is need to have pumpkin fruit value addition options made available in the markets to provide more convenience foods which are preferred more by urban dwellers. Value addition should promote consumption of the pumpkin fruit by a larger proportion of people, thus promote nutrition and food security status, as well as provide an avenue for the market to demand pumpkin fruit which will automatically increase marketability.

It is further concluded that whole pumpkin fruit has the longest shelf-life, averaging 142 days in the present study, while slicing the fruit drastically reduces this period to about 3-4 days. Wrapping sliced pumpkin fruit slightly extends shelf-life by protecting from excessive weight loss as well as microbial attack and decay.

Majority of consumers prefer buying quarter slices of pumpkin fruit as opposed to other presentation formats. Although offering pumpkin fruit in various presentation formats does not significantly enhance sale, it is evident that bigger slices are not preferred by most consumers, compared to quarter slices. Adoption and promotion of pumpkin presentation in superior formats that extend shelf-life in local markets is recommended to help increase pumpkin utilization in Kenya.

\section{Acknowledgements}

We acknowledge the financial support received from the Kenya Agricultural Productivity and Agribusiness Programme (KAPAP) which made this research possible.

\section{References}

[1] Oniang'o, R. K., Shiundu, M. K., Maundu, P. and Johns, T. (2005) African leafy vegetables: Efforts to change a traditionally subsistence crop into a major driver in poverty alleviation and improvement of health in Sub-Saharan Africa. International Consultation on the Value of Bio-diversity in Achieving the UN Millennium Development Goal of Freedom from Hunger and Poverty. Chennai, India.

[2] Kiramana, J. K. and Isutsa, D. K. (2017) Documentation of indigenous traditional knowledge determining cultivation and utilization of pumpkins in Kenya. Journal of Environmental Sustainability Advancement Research, 3, 17-31.

[3] Kiramana, J. K. and Isutsa, D. K. (2017) First detailed morphological characterisation of qualitative traits of extensive naturalized pumpkin germplasm in Kenya. International Journal of Development and Sustainability, 6(7), 500-525.

[4] Kiramana, J. K. and Isutsa, D. K. (2017) Morphological characterization of naturalised pumpkin (Cucurbita moschata (Lam.) Poir.) accessions in Kenya. African Journal of Horticultural Science, 12, 61-83.

[5] Kiramana, J. K., Isutsa, D. K. and Nyende, A. B. (2016) Evaluation of quantitative yield performance of pumpkin accessions in Kenya using mother trials. International Journal of Advanced Biological Research 6(4), 439-447.

[6] Kiharason, J. W. Isutsa, D. K. and Ngoda, P. N (2017) Effect of drying method on nutrient integrity of selected components of pumpkin (Cucurbita moschata Duch.) fruit flour. Journal of Agricultural and Biological Sciences, 12(3), 110-116.

[7] Kiharason, J. W., Isutsa, D. K. and Ngoda, P. N. (2017) Evaluation of sensory acceptability of bakery products prepared from wheat and pumpkin composite flour. International Journal of Science and Nature. 8 [1], 1-7.

[8] Kiharason, J. W., Isutsa, D. K. and Ngoda, P. N. (2017) Nutritive value of bakery products from wheat and pumpkin composite flour. Global Journal of Biosciences and Biotechnology, 6(1), 96-102.

[9] Onyango, M. O. A., Habwe, F. O. and Walingo, M. K. (2008) Food processing and preparation technologies for sustainable utilization of African indigenous vegetables for nutrition security and wealth creation in Kenya. Int. Union Food Sci. Technol. Chapter 13, 1-9.

[10] Chavasit, V., Pisaphab, R., Sungpuag, P., Jittinandana, S. and Wasantwisut, E. (2002) Changes in beta carotene and vitamin a contents of vitamin a-rich foods in Thailand during preservation and storage. Journal of Food Science 67, 375-379.

[11] Kiaya, V. (2014) Post-harvest losses and strategies to reduce them: Technical paper on post-harvest losses. Scientific and Technical Department, Action Contre la Faim (ACF), member of ACF International.

[12] Kader, A. A. (2002) Post-Harvest Technology of Horticultural Crops. $3^{\text {rd }}$ ed. Univ. Calif. Agr. Nat. Resources, Oakland, Publ. 3311 .

[13] Masarirambi M. T., Mavuso V, Songwe V. D., Nkambule T. P. and Mhazo, N. (2010) Indigenous post-harvest handling and processing of traditional vegetables in Swaziland: A review. African Journal of Agricultural Research 5(24), 3333-3341. 
[14] Kitinoja, L. and Kader, A. A. (2015) Measuring post-harvest losses of fresh fruits and Vegetables in developing countries. PEF White Paper 15-02, September 2015. The Post-Harvest Education Foundation.

[15] Spore. (2011) Post-Harvest Management. Adding Value to Crops. The magazine for agricultural and rural development in ACP countries. N 152. http://spore.cta.int.

[16] Kitinoja, L., Saran, S., Roy, S. nK. and Kaderc, A. A. (2011) Post-harvest technology for developing countries: Challenges and opportunities in research, outreach and advocacy. J Food Sci Agr, 91, 597-603.

[17] Sharma, N., Garcha, S. and Singh, S. (2013) Potential of Lactococcus lactis subspecies MTCC 3041 as a biopreservative. J Microbio Biotech Food Sci, 3 (2), 168-171.

[18] O'connor-Shaw, R. E., Roberts, R. and Ford, A. L. (1996) Changes in sensory quality of sterile cantaloupe dices stored in controlled atmosphere. J Food Sci, 61, 847-851.

[19] Saranraj, P., Stella, D. and Reetha, D. (2012) Microbiological spoilage of vegetables and its control measures: A review. Int J Natur Prod Sci, 2 (2), 1-12.

[20] Lequeu, J., Fanconnier, M. L., Chammai, A., Bronner, R. and Blee, E. (2008) Formation of plant cuticle: Evidence of the occurrence of the peroxygenase pathway. Plant J, 36, 155-164.

[21] Barth, M., Hankinson, T. R., Zhuang, H. and Breidt, F. (2009) Microbial spoilage of fruits and vegetables. In: W. H. Sperber, M. P. Poyle (eds). Compendium of the Microbiological Spoilage of Foods and Beverages, Microbiology and Food Safety, Springer Science + Business Media.

[22] Subrahmanyam, K. (1986) Post-harvest losses in horticultural crops: An appraisal of agricultural situation in India. 41, 339343 .

[23] Fedha, M. S., Mwasaru, M. A., Njoroge, C. K., Ojijo, N. O. and Ouma, G. O. (2010) Effect of drying on selected proximate composition of fresh and processed fruits and seeds of two pumpkin species. Agriculture and Biology Journal of North America, 1(6), 1299-1302.

[24] Mnzava, N. and Mbewe, J. E. (1997) African traditional vegetables. Selecting dual-purpose local pumpkins Cucurbita moschata (Duch. ex Lam.). Report.

[25] Arnum, S. D. (1998) Vitamin A in Kirk-Othmer Encyclopedia of Chemical Technology. New York: John Wiley. p. 99-107.

[26] Oloyede, F. M., Agbaje, G. O. and Obisesan, I. O. (2013)
Effect of NPK fertilizer on fruit yield and yield components of pumpkin (Cucurbita pepo Linn.). African Journal of Food, Agriculture, Nutrition and Development, 13, 1684-5374.

[27] Encyclopedia of Foods and Their Healing Power: Volume 1 (2004) Education and Health Library Editorial Team (Ed). 2004, ISBN-10:8472081842.

[28] Isutsa, D. K., Munyoro, D. W. and Gaoqiong, L. (2017) Effects of mineral nutrient source and leaf harvesting intensity on pumpkin (Cucurbita moschata Duch.): 1. Edible growth and quality components. Journal of Environmental Sustainability Advancement Research, 3, 32-41.

[29] Isutsa, D. K. and Mwaura, M. M. (2017) Effects of irrigation rate and leaf harvest intensity on multi-purpose pumpkin (Cucurbita moschata Duch.) growth and quality. International Journal of Development and Sustainability 6(9), 1121-1141.

[30] Blessing, A. C., Ifeanyi, U. M. and Chijioke, O. B. (2011) Nutritional evaluation of some Nigerian pumpkins (Cucurbita spp.). Fruit, Veg. Cereal Sci. Biotech., 5(2), 64-71.

[31] Muendo, K. M. and Tschirley, D. (2004) Improving Kenya's domestic horticultural production and marketing system: Current competitiveness, forces of change, and challenges for the future. Vol. I: Horticultural Production. Working Paper No. $08 \mathrm{~A} / 2004$.

[32] Ondigi, A. N., Toili, W. W., Afisihi, S. M. and Stanley, O. O. (2008) Comparative analysis of production practices and utilization of pumpkins (Curcubita pepo and Curcubita maxima) by smallholder farmers in the Lake Victoria Basin, East Africa. African Journal of Environmental Science and Technology, 2(9), 296-304.

[33] Kiharason, J. W., Isutsa, D. K. and Ngoda, P. N. (2015) Contribution of multi-purpose pumpkin (Cucurbita moschata Duch.) to the economy of selected Kenyan small-scale households. Journal of Environmental Sustainability Advancement Research, 1:8-14.

[34] Hamisy, W. C., Makundi, A. H., Marandu, D., Nkya, M. J. (2002) Evaluation of five accessions of Cucurbita maxima collected from different ecological zones in Tanzania. The Second International Workshop on Plant Genetic Resources and Biotechnology Report, Arusha, Tanzania, p. 6-10.

[35] Ndoro, O. F., Madakadze, R. M, Kageler, S. and Mashingaidze, A. B. (2007) Indigenous knowledge of the traditional vegetable pumpkin (Cucurbita maxima/moschata) from Zimbabwe, African Journal of Agricultural Research, 2(12), 649-655. 